\title{
THE SOFTWARE METHODS OF ASSESSING PERFORMANCE, QUALITY AND FUNCTIONALITY OF THE FRAME CONFIGURATION EQUIPMENT
}

\author{
S. M. PIVEN*, V. V. RACHINSKIY
}

Department of transport system and technical services, Kherson National Technical University, Kherson, UKRAINE

*email:pivensn@ukr.net

\begin{abstract}
The problems associated with using of software-hardware provision of mechanisms with parallel structure in computeraided simulation are considered. A comprehensive methodology for assessing and comparing new configurations mechanism parallel structure machine-tool equipment created. This methodology can be usedfor reconfiguration calculation in order to direct selection of technical features at the early stages of design. A new complex assessment approach to evaluate performance, quality and functionality of the equipment frame configurations is shown. Mathematical and software methods of kinematics problems solution and drives control; elastic (rigidness) state evaluation are presented. The model and hierarchical multimodal application is developed for any new parallel structure mechanism machine-tool configurations, with simultaneous parameter estimation and dynamic rigidness response simulation is presented by line of computer programs "Tools Glide", "Tools Response", "Tools App". These programs allow analyzing of any designed layout properties and making choice of structural components, blocks and links during design process. The kinematic and kinetostatic analysis methods assessing performance, quality and functionality options and calculated data can be obtained by the line of "Tools" software products. Test calculations and test processing using different scenarios shows compliance to expected results, constructional algorithm of equation system, synthesis easiness for equations with different types of connections that gives possibility of successful use of these software products in automated modelling sys tems and CAM systems. This software tested as external post-processor on drilling - milling machine-tool prototypes with mechanism of parallel structure in the mechanical laboratory

Keyword: mechanism parallel structure machine-tool; early stages of design; kinematic and kinetostatic analysis; computer programs "Tools Glide"; "Tools Response"; "Tools App".
\end{abstract}

\section{ПРОГРАМНІ МЕТОДИ ОЦНКИ РОБОТИ, ЯКОСТІ ТА ФУНКЦОНАЛЬНОСТІ ОБЛАДНАННЯ КАРКАСНИХ КОМПОНОВОК}

\section{С. М ПІВЕНЬ, В. В. РАЧИНСЬКИЙ}

Кафедра транспортних систем і технічного сервісу, Херсонський національний технічнийуніверситет, Херсон, УКРАЇНА

\begin{abstract}
АННОТАЦІЯ Створено методику оцінки і порівняння якості нових компоновок верстатного обладнання з механізмами паралельної структури без детального конструкторського опису із врахуванням їх реконфігурації для спрямованого відбору очікуваних технічних характеристик на ранніх стадіях проектування. Розроблено модель та багатомодульну ієрархічну програму для створення програм керування нових компоновок верстатів з механізмами паралельної структури 3 одночасною оцінкою параметрів жорсткості і динамічного відгуку ланок при виконанні технологічних переходів обробки складнопрофільних поверхонь. Розглянуті питання, пов 'язані з програмно-апаратним забезпеченням механізмів паралельноі структури в системах автоматизованого моделювання. Розроблено програмудля розрахунку зворотної задачі кінематики для механізмів паралельної структури, яка в свою чергу може використовуватися як пост-прочесор для визначення працездатності будь-якої нової компоновки верстатів. Наведено варіанти методів аналізукінематики і розрахунку даних, отриманих в системах комп'ютерної математики на прикладі лінійки програм розроблених на кафедрі транспортних систем і технічного сервісу Херсонського начіонального технічного університету "Tools Glide», «Tools Response», «Tools Арр». Також перевірена робота циих програм як зовнішнього пост-проиесору на дослідних зразках свердлильно-фрезерних верстатів з механізмами паралельної структури, що використовуються в механічній лабораторії кафедри транспортних систем і технічного сервісу Херсонського начіонального технічного університету
\end{abstract}

Ключові слова: механізми паралельної структури; відбір очікуваних технічних характеристик на ранніх стадіях проектування; лінійка програм «Tools Glide»; «Tools Response»; «Tools App».

\section{Introduction}

Modern market gives tasks for manufacturing plants, the nature of which is changing very rapidly. Plants have to get processing equipment with variety of machine-tools which allow to fulfill customer new requirements with minimum investment in new machinetool equipment. This problem can be solved by using a multi-dimensional hinge rod mechanisms with parallel structure (MPS) combined with limited number of modules in machine-tool frame layout and with possibility of restructuring (reconfiguration) them in new frame layout [1]. Time limit for the design forces to use computer programs to assess performance, quality and functionality of the equipment frame configurations.

(c) S. M. PIVEN, V. V. RACHINSKIY, 2016 


\section{The purpose of the work}

The first and most important stage of the design phase is a selection of main layout (configuration). However, there is a problem not only for prediction the necessary functionality for future layout, but also ensuring technical characteristics of the machine-tools with MPS at early stages of design [2]. The aim is to create comprehensive methodology for assessing and comparing new configurations parallel structure machine-tool. This system has to include mathematical and software methods of kinematics problems solution and drives control; elastic (rigidness) state evaluation are presented.

\section{The main material}

As synthesis basis is a combination of frame and guide mounting multivariateness, defined as

$$
C(n, m)=(n+m-1) ! / m !(n-1) !
$$

where $n$ - number of rods (rails) $m$ - permutation capacity. The geometrical properties of machine-tool base are determining the quantity of permutation variety $\mathrm{m}$. Therefore the presence of quite many variants force to give up the algorithm of manual sorting and abandon the using of engineering intuition to select the most optimal choice. Also the presence of a huge amount of information that should be analyzed in the process of selecting configurations push to look for a new complex assessment approach to evaluate performance, quality and functionality of the equipment frame configurations [3]. This analyze includes: structural circuit synthesis procedures based on processed work-piece geometric image; mathematical and software methods of kinematics problems solution and drives control; elastic (rigidness) state evaluation and machine-tools with MPS dynamic responses in the equipment ranges of operations [4]. Take for example several options where immobile kinematic structure and traditional fixed bearing base workspace layouts limits the equipment in its internal space [5]. Genetic inversion operator [6] used for solving this problem at MPS with constant length rods and give a possibility to obtain a line of new layout configurations [7] for objects manipulation equipment with enhanced functionality and new features (fig. 1).

At fig. 2 shows an example of frame layout that can be rebuilt in space in order to increase workspace of MPS and to manage elastic compliances of loading force at given direction action. The basis of valuation, quality and functionality of the equipment frame configurations assigned a set of programs developed at Kherson National Technical University Department of design together with National Technical University of Ukraine "Igor Sikorsky KPI" Department of design tools and machines "Tools App" [8], "Tools Glide" [9], "Tools Response".

These computer programs based on methods of analytic geometry, vector analysis, calculus of variations, finite element, tensor calculus $[10,11,12]$. These programs allow to analyze of any designed layout properties and makes choice of structural components, blocks and links during design process.

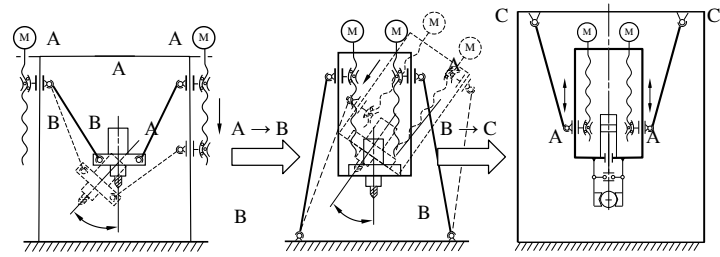

a)

b)

c)

Fig. 1 -Circuit realization inversion for new properties manipulation systems with MPS (a) - traditional glide-layout; (b)-drives and carriage are moved to the mobile platform; $(c)$ - rods fastening transferred to another (any) surface [7]

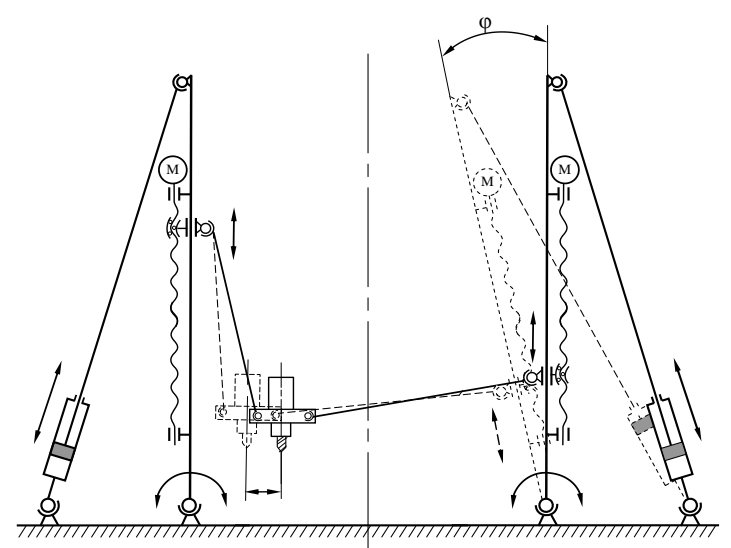

a)

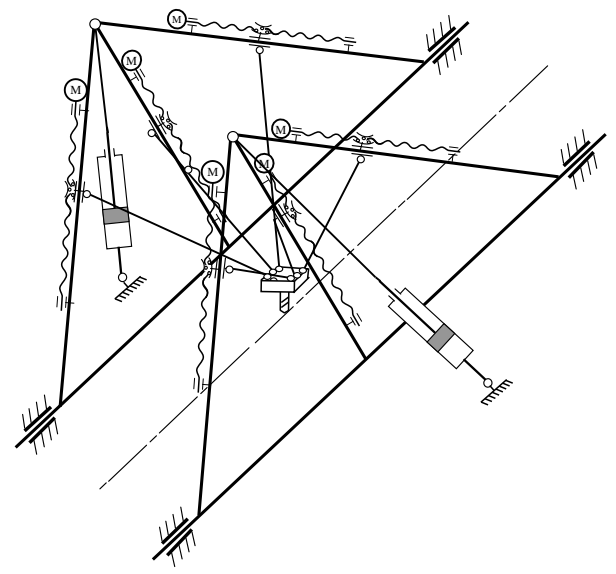

b)

Fig. 2 - Frame layout of MPS with reconfiguration capacity: a)-structural scheme; b) - kinematic scheme [7]

The basic of work on CNC equipment is creating work-piece processing program, which is set to CAM surface processing module in order to receive a file called CL-data (cut-location data). This file presents coordinates of basic points of end-effectors trajectory with tool vectors. Based on this file computer program "Tools Glide" calculates kinematics inverse problem solution and calculates 
corresponding machine-tool end-effector coordinate for each work-piece coordinate from CL-data list.

"Tools Response" calculates rigidness and compliance parameters, strength characteristics of complex multistage structures, interference with levels of mobility expectation for any components, assemblies and joints sets (fig. 3). Obtained data transmitted to analyze into "Tools App" dynamic properties module. Structure of software modules "Tools Glide" and "Tools Response" composed of blocks of kinematics and stiffness (compliance) blocks.

Kinematic block ("Tools Glide ") gives possibility of forming glide-equipment layout and kinematic calculation with "Tools Response" feedback module for simulating of various types hinges. Obtained data can be transferred to "Tools App" module, where technical system properties described as dynamic compliance function, which characterizes technical system response in the form of displacements for given force excitation.

There is an approach used to describe a trajectory of system with presence of holonomic constraints. This approach is an extension of the previous method, where holonomic constraint describes possible trajectory of a restrained point using the equation $f(x, y, z, t)=0$. In terms of force holonomic constrain description, assume that movement deviation of the normal to surface allowed to move or curve allowed to move causes infinite by module forces acting against deviation. As a result, this force description has two problems: an infinite module forces is hard to fit with calculation algorithms, and change of force direction along allowed by restrain surface (curve) complicates the mathematical description. In addition holonomic constrain describes only geometry, without force description, also fails to take into account system inertial properties [13].

To simplify this task proposed to describe constrain reaction forces introducing, by analogy with virtual holonomic constrain, virtual potential which has minimum at constraint allowed space, and growing rapidly (ideally - drastically) with deviation [14, 15] .That provides force with zero value in allowed points and gives appearance of infinite force in efforts make movement by normal to allowed surface (curve). This growth is modeled using delta functions. It is easier to use for calculation one of the following delta function approximations:

either polynomial

$$
\delta(x)=\lim _{\alpha \rightarrow \infty} \frac{\alpha}{\pi\left(1+\alpha^{2} x^{2}\right)} ;
$$

or exponential

$$
\delta(x)=\lim _{\alpha \rightarrow \infty} \frac{\alpha}{\sqrt{\pi}} \exp \left(-\alpha^{2} x^{2}\right)
$$

where controlling the value of the parameter $\alpha$ it is possible to achieve required degree of approximation $[16,17]$.
Kinematic models analysis by the virtual potential method gives opportunity to narrow down possible solutions space and considers different hinges types kinematics property. "Tools Glide" implements this method as "Virtual potential scenario" option (fig 3. c).

Table 1 - Selected basic layout (frame configuration) for machine-tools with parallel kinematic structure $[1,18,19,20]$

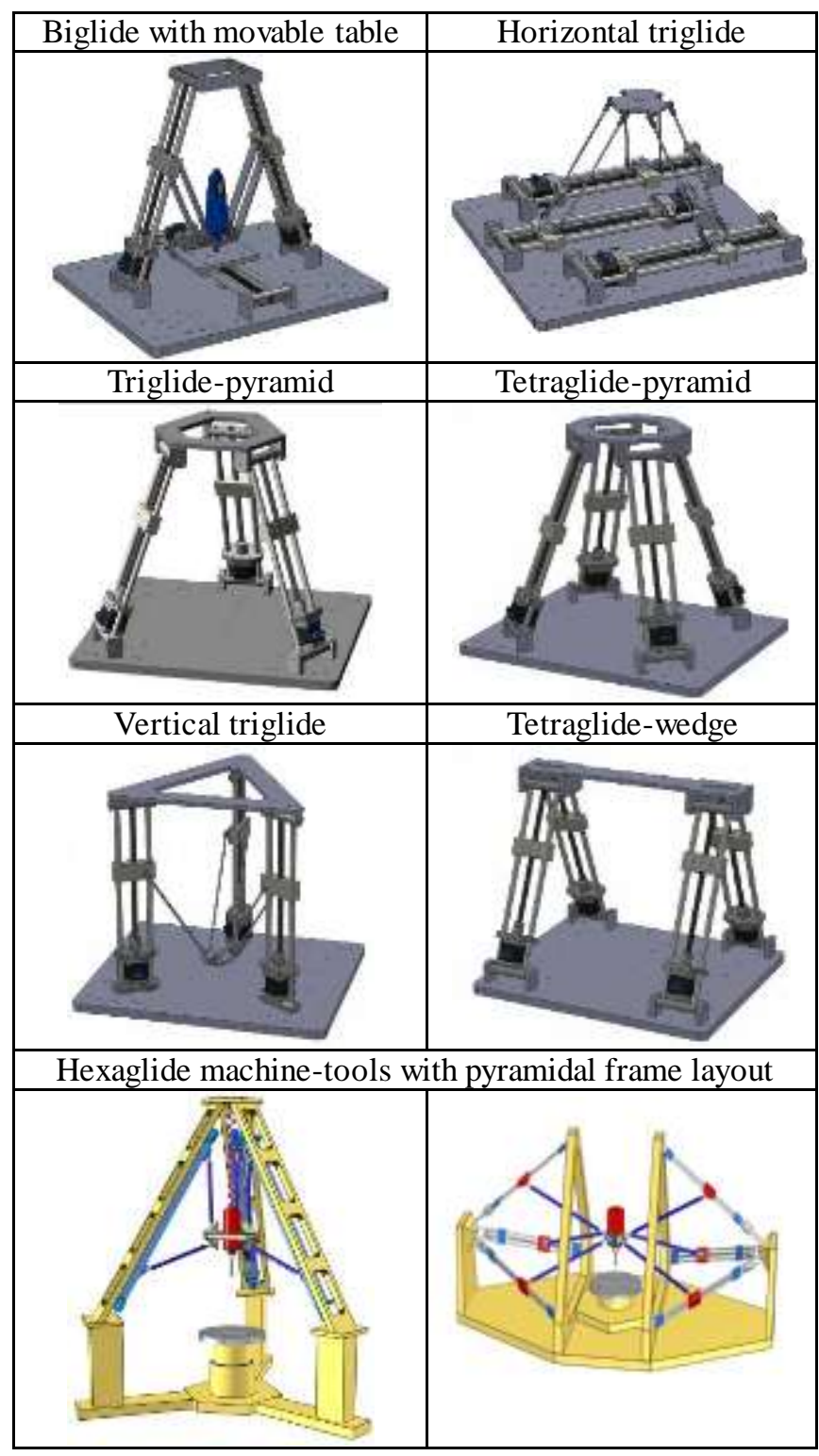

Last two methods used complex computer-aided modelling software "Tools" that allow to solve kinematic problem (direct and inverse problem) for machines with MPS, to calculate elastic (stiffness) and dynamic characteristics of the machine with consideration of different types of joints, to calculate cutting forces and moments tasks, to make equipment dynamic analysis, and to obtain frequency characteristics at the design stage of layout options research. 

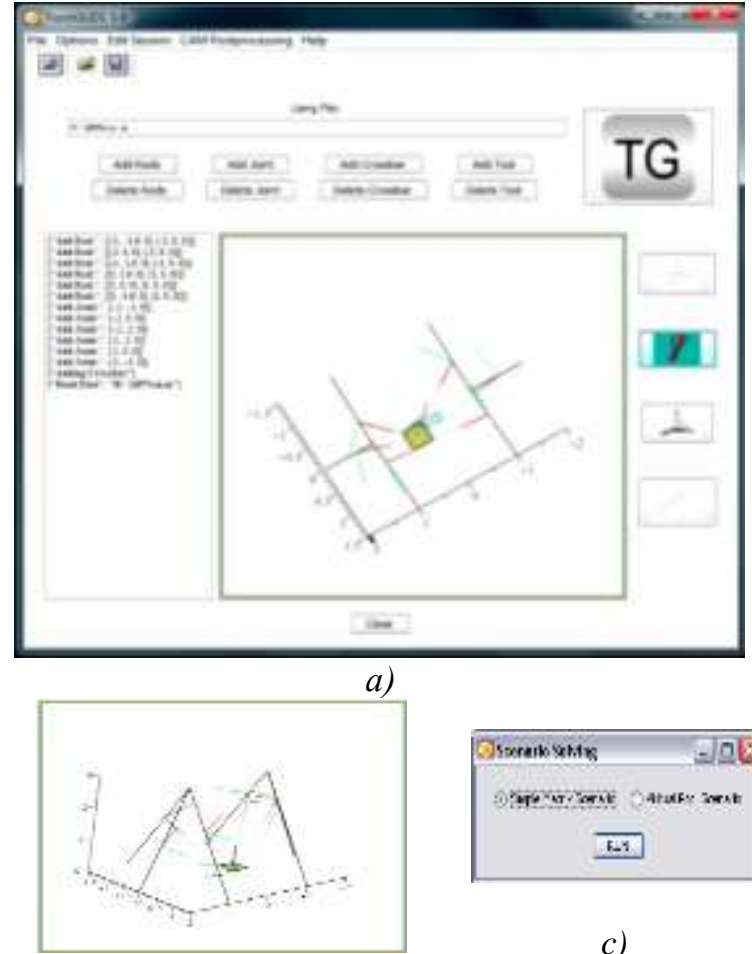

b)

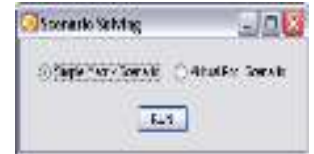

c)

Fig. 3 - "Tools Glide" main window interface (a), animated visualization "Tools Glide" processing strategy (b), models search and selection in decisions space (c) [9]

"Tools Glide" system (fig.3, a) conducted kinematic analysis by one of its mode either "Simple matrix scenario" or "Virtual potential scenario". (fig.3, c) In accordance with imported paths and tool orientations file (can be used CL-data file from another CAM systems) the program calculates inverse kinematic problem solution, exports data to the post processor, produces data for other types of analysis, and makes animation workflow (fig. 3 b). Also this software uses to analyze efficiency and design of control programs for pyramidal type machine-tools with mechanisms of parallel structure. The variants of layout of MPS from table 1 were simulated and calculated by line of "Tools" computer products. "Tools Glide", "Tools Response" and "Tools App" are used also as post-processor software for test-bench machine-tools (fig 4, 5) in a mechanical laboratory of Kherson National Technical University Department of transport system and technical services.

These are drilling-milling pyramidal type MPS machine-tool prototype SFVPK-3 (fig.4, a), drillingmilling pyramidal type MPS machine-tool prototype SFVPK-4 (fig.5 a, b) and hexaglide test-bench multipurpose machine-tool (fig.4, b). These machine-tool prototypes with mechanism of parallel structure not only using for scientific and university research programs but also for familiarizing students with modern models of mechanisms with parallel structure.

One of aspect of testing was receiving of vibrograms by piezoelectric cells with the values of the damping coefficient $h$ and overall appearance of the stand to measure vibration by using high frequency accelerometers [13]. The same vibrograms were simulated by "Tools" software and total compliance to received by test results shown. Programs "Tools Glide", "Tools Response", "Tools App" were tested using different scenarios. Tests show compliance to expected results, constructional algorithm of equation system, and synthesis easiness for equations with different types of connections that gives possibility of successful use of programs "Tools Glide", "Tools Response", "Tools App" software products in automated modelling systems and CAM systems. Apart of using for early stages of design the software line "Tools" uses as one of many existing versions of CAM-processing programs testing on those machine-tools.

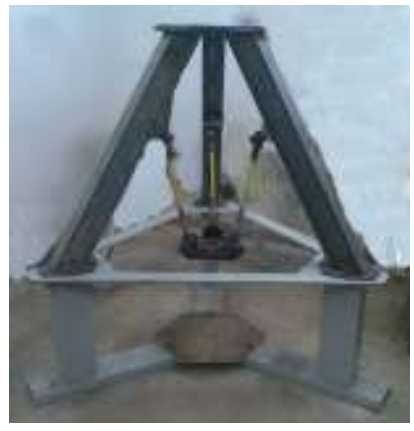

a)

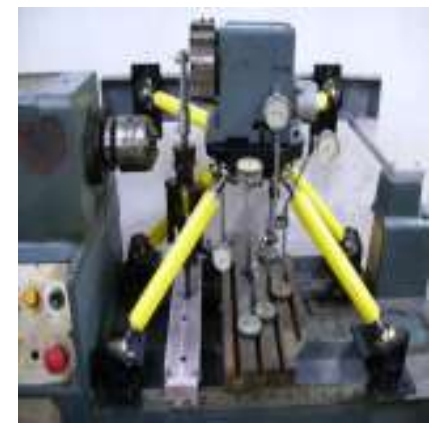

b)
Fig. 4 - (a) drilling and milling machine-tool prototype with mechanism of parallel structure SFVPK-3 (b) - multi-purpose machine-tool hexaglide [19]

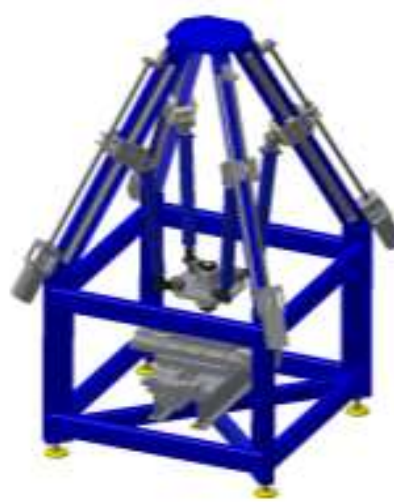

a)

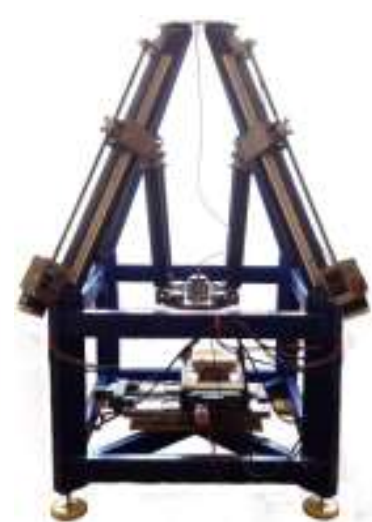

b)
Fig. 5 - Drilling and milling machine-tool prototype with mechanism of parallel structure SFVPK-4 (a) scheme of the machine, (b) view

Dynamic model of program "Tools App" is based on second-order differential Lagrange equations. For $n$ - 


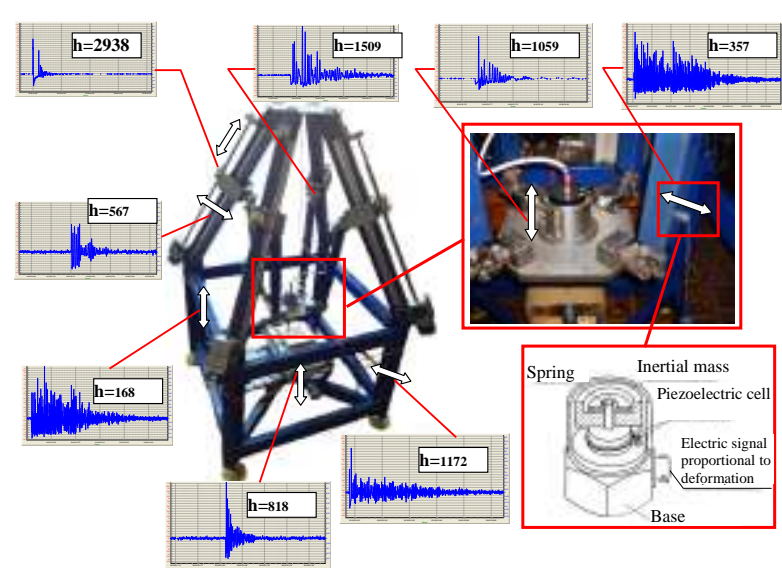

Fig. 6 - Vibrograms received by some elements of the machine-tool SFVPK-4 [14]

( $h$-dumping coefficient, sec $^{-1}$ )

power mechanism mathematical model Lagrangian form is converted to the form $[15,16]$ :

$$
\mathbf{I}(\mathbf{q}) \frac{d^{2} \mathbf{q}}{d t^{2}}+\mathbf{h}\left(\mathbf{q}, \frac{d \mathbf{q}}{d t}\right)=\mathbf{Q}
$$

where $\mathbf{q}, \frac{d \mathbf{q}}{d t}, \frac{d^{2} \mathbf{q}}{d t^{2}}$ - respectively generalized coordinates vector $(n \times 1)$, velocity vector $(n \times 1)$ and acceleration vector $(n \times 1) ; \mathbf{I}(\mathbf{q})$ - mechanism inertia matrix; $\mathbf{h}\left(\mathbf{q}, \frac{d \mathbf{q}}{d t}\right)-$ centrifugal vector (nx1), Coriolis force vector $(\mathrm{nx} 1)$ and dissipative forces vector $(\mathrm{nx} 1) ; \mathbf{Q}$ - forces sum vector (nx1) applied to mechanism links and joints.

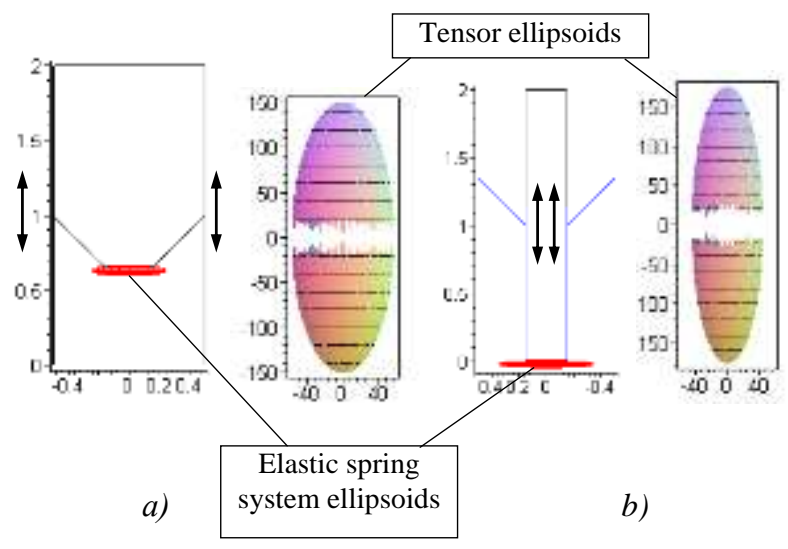

Fig. 7 -Results of program "Tools Response" calculation - compliance ellipsoids and elastic displacement of MPS frame configurations tensor ellipsoids: a - classical glide scheme with guide rails and carriages on stationary base (fig. 1, a); b-inverse glide scheme with the guide rails and carriages on a mobile platform (fig. 1, c)

At fig. 7 shows calculation and comparison of tensor ellipsoids $(\hat{T} r) r=1$ of the two frame layouts of machine-tools with the MPS (fig.1, a) - "classic scheme" and scheme obtained by inversion (fig.1 b, c) with the same physical properties of the elements. Where $\mathrm{T}-$ compliances tensor, $\mathrm{r}$ is force $\mathrm{P}$ vector, then $\widehat{\mathbf{T P}}=\mathbf{u}$, where $\mathrm{u}$ is vector of displacement under force $\mathrm{P}$ action, and surface is surface $(T P) P=$ const is a level proportional to the given force effort executes given work in specified direction $[18,19]$.
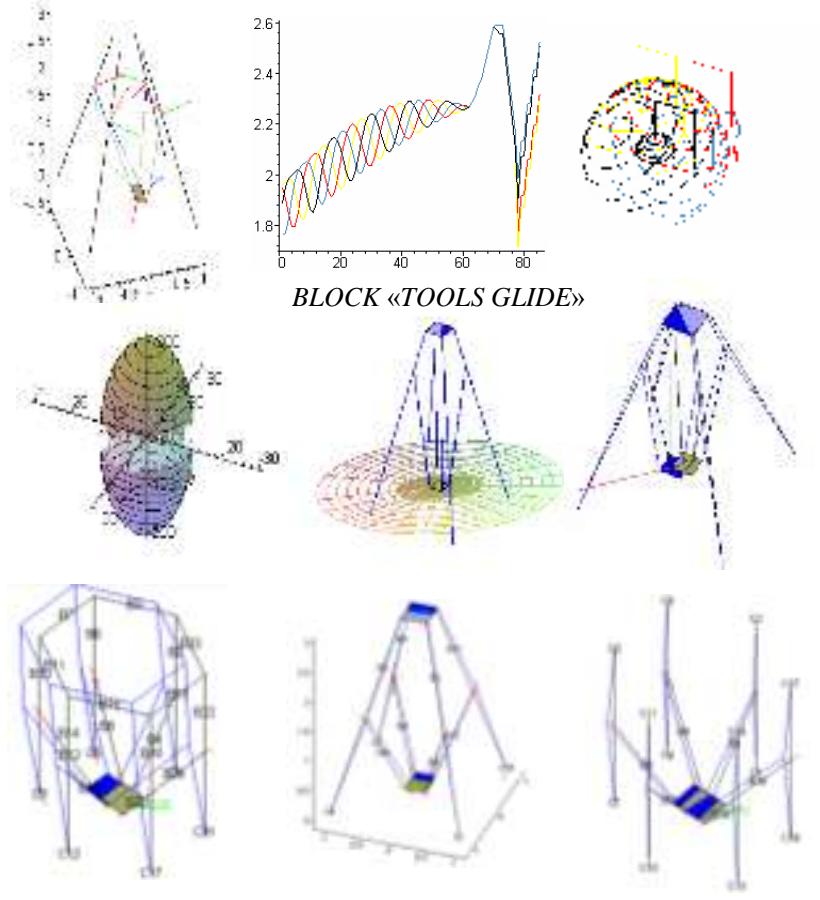

BLOCK «TOOLS RESPONSE»

Fig. 8-Intermediate graphics objects of "Tools Glide" and "Tools Response" blocks

Feedback between modules (import-export) provides ability to take into account mutual influence "kinematics - deformation response". This feature ensures optimal prognoses for different equipment configurations [19].

Obtained data can be transferred to "Tools App" module, where technical system properties described as dynamic compliance function, which characterizes technical system response in the form of displacements for given force excitation.

Each technological system has own response characteristic describing system features [20]. Therefore any technological equipment characteristic can be determined by a computer program, allowing to use the "Tools" software at primarily design stage for machinetool with MPS. 


\section{Conclusions}

A comprehensive methodology for assessing and comparing new configurations MPS machine-tool equipment created. This methodology does not need a detailed design description for reconfiguration calculation in order to direct selection of technical features that expected in the early stages of design. The model and hierarchical multimodal application is developed for any new MPS machine-tool configurations, with simultaneous parameter estimation and dynamic rigidness response during performing of technological processing complex geometry work-piece. The kinematic and kinetostatic analysis methods assessing performance, quality and functionality options and calculated data can be obtained by the line of "Tools" software products. Test calculations and test processing for different layout (frame configurations) using both scenarios (simple matrix and virtual potential) shows compliance to expected results, constructional algorithm of equation system, synthesis easiness for equations with different types of connections that gives possibility of successful use of programs "Tools Glide", "Tools Response", "Tools App" software products in automated modelling systems and CAM systems. This software tested as external post-processor on pyramidal type drilling - milling machine-tool prototypes with mechanism of parallel structure SFVPK3, SFVPK-4, and the others in the mechanical laboratory of Kherson National Technical University.

\section{Bibliography (translite rated)}

1. Kuznetsov, Yu. N., Dmitriev, D. A., Dinevich, G. Yu. Configuration of machine-tools with mechanisms of parallel structure: Monograph. Kherson: PE Vyshemyrskyy V.S., 2009, $456 \mathrm{p}$.

2. Zhang, D. Kinetostatic Analysis and Optimization of Parallel and Hybrid Architectures for Machine Tools, Ph.D.

Thesis, Laval University, Canada, 2000, 288 p.

3. Liu, X. J., Wang, J. S., Pritschow, G. A new family of spatial 3-DoF fully-parallel manipulators with high rotational capability, Mech. Theory, 2005, 40, 475-494. doi: 10.1016/j.mechmachthe ory.2004.10.001.

4. Zhang, D., Bi, Z. M., Li, B. Z. Design and kinetostatic analysis of a new parallel manipulator. Robot. Comput.Integr. Manuf. 2009, 25(4-5), 782-791, doi 10.1007/s10999-012-9197-3.

5. Kuznetsov, Yu. N., Dmytriev, D. A., Rusanov, S. A., Piven, S. M. Method of determining dynamic characteristics of machine with bar support system, Journal of the Technical University of Gabrovo, 2016, 52, 18-23.

6. Kuznetsov, Yu. N., Shinkarenko, V. F. Genetic approach key to creating complex technical systems. Scientific journal "Technological complexes", 2012, 1,2(5,6), 15 - 29.

7. Kuznetsov, Yu. M., Bardachov, Yu. M., Dmitriev, D. O., Piven', S. M. "Mekhanizm manipulyuvannya obektami v tekhnologichnomu obladnanni" [The mechanism of manipulating objects in technological equipment], The application for invention number of a201512568 from 21/12/2015.

8. Rusanov, S. A., Kuznctsov, Yu. M., Dmitriev, D. O., Podol's'kiy, M. I. "Komp'yuterna programa «Tools App»
[Computer program« Tools App»] Certificate of registration of copyright - № 57913 from 29.12.2014 - State Intellectual Property Service.

9. Rusanov, S. A., Kuznetsov, Yu. M., Dmitriev, D. O., Keba, P. V. "Komp'yuterna programa «Tools Glide» [Computer program «Tools Glide»] Certificate of registration of copyright - № 66227 from 21.06.2016 - State Intellectual Property Service.

10. Borisenko, A. I., Tarapov, I. E. Vektornyy analiz i nachala tenzornogo ischisleniya [Vector analysis and the beginning of the tensor calculus]. Vysshaya shkola [High school]. Moskow, 1966, $250 \mathrm{p}$.

11. Svetlitskiy, V. A. Mekhanika gibkikh sterzhney i nitey [Mechanics of flexible rods and threads]. Moskow: Mashinostroenie, 1978, $222 \mathrm{p}$.

12. Poduraev, Yu. V. Mekhatronika: osnovy, metody, primenenie [Mechatronics: fundamentals, methods, application]. - Moskow: Mashinostroenie, 2006, 286 p.

13. Dmitricv, D. O., Kuznctsov, Yu. M., Rusanov, S. A., Keba, P. V. Perekhidni dinamichni protsesi v tekhnologichnomu obladnanni karkasnogo komponuvannya [Transient dynamic processes in technological equipment frame layout]. Materiali konferentsii "Suchasni tekhnologii promislovogo kompleksu" [Proceedings of the conference "Modern technologies of industrial complex"], KhNTU, Kherson, Ukraïna, 2016, 89-91.

14. Maggiore, M., Consolini, L. Virtual Holonomic Constraints for Euler-Lagrange Systems. IEEE Transactions on Automatic Control. 2013, 58(4),1001-1008, doi; 10.1109/TAC.2012.2215538.

15. Baganov, C. O. Rusanov, S. A., Piven', S. M. Vikoristannya variatsiynogo pidkhodu dlya kinematichnogo analizu mekhanizmiv paralel'noï strukturi v sistemakh avtomatizovanogo modelyuvannya [Using variational approach for kinematic analysis of mechanisms of parallel structure in computer-aided simulation]. Visnik Khmel'nits'kogo natsional'nogo universitetu [Bulletin of Khmelnytsky National University], 2016, 3, 41-45.

16. Gebel, E. S., Mathematical Modeling of Dynamics of MultiLever Linkages, Procedia Engineering, 2015, 100, 15621571, doi: 10.1016/j.proeng.2015.01.529.

17. Stachera, K., Schumacher, W. Derivation and Calculation of the Dynamics of Elastic Parallel Manipulators. Automation and Robotics, 2008, doi: 10.5772/6108.

18. Kuznetsov, Yu. N., Podolsky, M. I., Dmitriev, D. A., Rusanov, S. A. Dynamic analysis of support lathe based parallel mechanisms of type "heksahlayd". Interuniversity collection "Scientific notes". Lutsk, 2013, 41(2), 69 - 73.

19. Kuznetsov, Yu. N., Dmytriev, D. O. Hybrid layout concept of machine-tools with parallel kinematic based on the modular principle. Proceedings of international scientific conference "'Technique, technology and systems Tekhsis 2009", Plovdiv, Technical University Sofia, 2009, 19-36.

20. Dmytriev, D. O. Description configurations of machinetools with the mechanisms of parallel structure. Scientific journal "Technological Complexes". 2011, 3, 18-30.

\section{Список літератури}

1. Кузнєцов, Ю. М. Компоновки верстатів з механізмами паралельної структури: Монографія / Ю. М. Кузнєцов, Д. О. Дмитрісв, Г. Ю. Діневич; під ред. Ю.М. Кузнєцова // Херсон: ПП Вишемирський В.С. - 2009. $456 \mathrm{c}$. 
2. Zhang, D. Kinetostatic Analysis and Optimization of Parallel and Hybrid Architectures for Machine Tools, Ph.D. Thesis, Laval University, Canada. - 2000. - 288 p.

3. Liu, X. J. A new family of spatial 3-DoF fully-parallel manipulators with high rotational capability / X. J. Liu, J. S. Wang, G. Pritschow // Mech. Mach. Theory, 2005, No 40, - P. 475-494. - doi: 10.1016/j.mechmachtheory. 2004.10.001.

4. Zhang, D. Design and kinetostatic analysis of a new parallel manipulator / D. Zhang, Z. M. Bi, B. Z. Li // Robot. Comput.-Integr. Manuf. - 2009. - № 25 (4-5), P. 782-791. - doi: 10.1007/s10999-012-9197-3.

5. Kuznetsov, Yu. N. Method of determining dynamic characteristics of machine with bar support system / Yu. N. Kuznetsov, D. A. Dmytriev, S. A. Rus anov, S. M. Piven // Journal of the Technical University of Gabrovo. - 2016. Vol. 52. - P. 18-23.

6. Кузнецов, Ю. Н. Генетический подход - ключ к созданию сложных технических систем / Ю. Н. Кузнецов, В. Ф. Шинкаренко // Науковий журнал «Технологічні комплекси». - 2012. - №1,2(5,6). C. $15-29$.

7. Кузнєцов, Ю. М., Бардачов, Ю. М., Дмитрісв, Д. О., Півень, С. М. "Механізм маніпулювання обєктами в технологічному обладнанні", Заявка на винахід № a201512568 від 21.12.2015.

8. Русанов, С. А., Кузнєцов, Ю. М., Дмитрієв, Д. О., Подольський, М. I. "Комп'ютерна програма «Tools Арр» - Свідоцтво про реєстрацію авторського права на твір № 57913 від 29.12.2014 - Державна служба інтелектуальної власності.

9. Русанов, С. А., Кузнєцов, Ю. М., Дмитрісв, Д. О., Кеба, П. В. "Комп'ютерна програма «Tools Glide» Свідоцтво про реєстрацію авторського права на твір № 66227 від 21.06.2016 - Державна служба інтелектуальної власності.

10. Борисенко, А. И. Векторный анализ и начала тензорного исчисления / А. И. Борисенко, И. Е. Тарапов // Высшая школа. - М.: 1966. - 250 с.

11. Светлицкий, В. А. Механика гибких стержней и нитей. - М.: Машиностроение. - 1978. - 222 с.
12. Подураев, Ю. В. Мехатроника: основы, методы, применение. - М.: Машиностроение - 2006. - 286 с.

13. Дмитрієв, Д. О. Перехідні динамічні процеси в технологічному обладнанні каркасного компонування / Д. О. Дмитрієв, Ю. М. Кузнєцов, С. А Русанов, П. В. Кеба // Матеріали конференції "Сучасні технологіi промислового комплексу". - ХНТУ, Херсон, Україна. 2016. - P. 89-91.

14. Maggiore, M. Virtual Holonomic Constraints for EulerLagrange Systems / M. Maggiore, L. Consolini // IEEE Transactions on Automatic Control. - 2013. - № 58(4). P. 1001-1008. - doi:10.1109/TAC.2012.2215538.

15. Баганов, Є. О. Використання варіаційного підходу для кінематичного аналізу механізмів паралельної структури в системах автоматизованого моделювання / С. О. Баганов С. А. Русанов, С. М. Півень // Вісник Хмельницького національного університету. - 2016. №3. - C. 41-45.

16. Gebel, E. S. Mathematical Modeling of Dynamics of MultiLever Linkages / E. S. Gebel // Procedia Engineering. 2015. - Vol. 100. - P. 1562-1571. - doi: 10.1016/j.proeng. 2015.01.529.

17. Stachera, K. Derivation and Calculation of the Dynamics of Elastic Parallel Manipulators / K. Stachera, W. Schumacher // Automation and Robotics. - 2008. - doi: 10.5772/6108.

18. Kuznetsov, Yu. N. Dynamic analysis of support lathe based parallel mechanisms of type "heksahlayd" / Y. N Kuznetsov, M. I. Podolsky, D. A. Dmitriev, S. A. Rusanov // Interuniversity collection "Scientific notes". Lutsk. - 2013. - №41 Vol. 2. - C. 69 - 73.

19. Kuznetsov, Yu. N. Hybrid layout concept of machine-tools with parallel kinematic based on the modular principle / Yu. N. Kuznetsov, D. O. Dmytriev // Proceedings of international scientific conference "'Technique, technology and systems Tekhsis 2009", Plovdiv, Technical University Sofia. - 2009. - P. 19-36.

20.Dmytriev, D. O. Description configurations of machinetools with the mechanisms of parallel structure / D. O. Dmytriev // Scientific journal "Technological Complexes". - 2011. - №3. - P.18-30.

\section{Сведения об авторах (About authors)}

Півень Сергій Миколайович - аспірант, кафедра транспортних систем і технічного сервісу, Херсонський национальний технічний університет; г. Херсон, Украина; e-mail: pivensn@ukr.net

Serhiy Piven - postgraduate student, department of transport system and technical services, Kherson National Technical

University, Kherson, Ukraine; e-mail: pivensn@ukr.net

Рачинський Владимир Витальевич - аспірант, кафедра транспортних систем і технічного сервісу, Херсонський национальний технічний університет; г. Херсон, Украина; e-mail:

Vladimir Rachinskiy - postgraduate student, department of transport system and technical services, Kherson National Technical University, Kherson, Ukraine; e-mail:

Please cite this article as:

Piven, S. M., Rachinskiy, V. V. The software methods of assessing performance, quality and functionality of the frame configuration equipment. Bulletin of NTU "KhPI". Series: New solutions in modern technologies. - Kharkiv: NTU "KhPI", 2016, 42 (1214), 103-110, doi:10.20998/2413-4295.2016.42.17.

Будь ласка посилайтесь на цию статтю наступним чином:

Півень, С. М. Програмні методи оцінки роботи, якості та функціональності обладнання каркасних компоновок / С. М. Півень, В. В. Рачинський // Вісник НТУ «ХПI», Серія: Нові рішення в сучасних технологіях. - Харків: НТУ «ХПІ». 2016. - № 42 (1214). - C. 103-110. - doi:10.20998/2413-4295.2016.42.17. 
Пожалуйста ссылайтесь на эту статью следующим образом:

Пивень, С. Н. Программные методы оценки работоспособности, качества и функциональности оборудования каркасных компоновок / С. Н. Пивень, В. В. Рачинский // Вестник НТУ «ХПИ», Серия: Новые решения в современных технологиях. - Харьков: НТУ «ХПИ». - 2016. - № 42 (1214). - С. 103-110 - doi:10.20998/2413-4295.2016.42.17.

АННОТАЦИЯ Создана методика оценки и сравнения качества новых компоновок станочного оборудования с механизмами параллельной структуры без детального конструкторского описания с учетом их реконфигурации для на правленного отбора ожидаемых технических характеристик на ранних стадиях проектирования. Разработана модель и многомодульная иерархическую структура для создания программ управления новых компоновок станков с механизмами параллельной структуры одновременно с оиенкой параметров жесткости и динамичного отклика звеньев механизма при выполнении технологических процессов обработки сложнопрофильных поверхностей. Рассмотрены вопросы, связанные с программно-аппаратным обеспечением механизмов параллельной структуры в системах автоматизированного моделирования. Разработана программа для расчета обратной задачи кинематики для механизмов параллельной структуры, в свою очередь, может использоваться как пост-процессор для определения работоспособности любой новой компоновки станков. Приведены варианты методов анализа кинематики и расчета данных, полученных в системах компьютерной математики на примере линейки программ разработанных на кафедре транспортных систем и технического сервиса Херсонского национального технического университета «Tools Glide», «Tools Response», «Tools App». Также проверена работа этих программ как внешнего пост-процессора на опытных образиах сверлильно-фрезерных станков с механизмами параллельной структуры, используемые в механической лаборатории кафедры транспортных систем и технического сервиса Херсонского начионального технического университета.

Ключевые слова: механизмы параллельной структуры; отбор ожидаемых технических характеристик на ранних стадиях проектирования; линейка программ «Tools Glide»; «Tools Response»; «Tools App». 